\title{
Implementation of Compulsory Study 12 Year Policy to Increase Education Quality in Kudus Regency
}

\author{
Asih Widi Lestari, Andy Fefta Wijaya, Siti Rochmah \\ Public Administrative Science \\ Administrative Science Faculty \\ Brawijaya University
}

\begin{abstract}
Education is an important instrument in improving the human resources quality. Kudus Regency has implemented compulsory study since 2010 through Kudus Regency Regional Regulation Number 2/ 2010 about Compulsory Study 12 (Twelve) Years. While, Central Government issued compulsory study 12 year policy in June 2013 through Ministry of Education and Culture Regulation Number 80/2013 about Universal Secondary Education. Obviously, this is a bold step of Kudus Regency Government in improving the education quality at Kudus Regency. The research objectives are: to know, analyze, and describe about Implementation of compulsory study 12 years policy to increase education in Kudus Regency; and to know, analyze, and describe about supporting and inhibiting factors toward implementation of compulsory study 12 years policy to increase education quality in Kudus Regency. This research resulted that the implementation compulsory study 12 years policy in Kudus Regency has been successfully, viewed from the actor that completely carry out their duties and responsibilities; the existence of funding and programs from Kudus Regency Government and Central Government is supporting the mechanism implementation in accordance with the provisions. The compulsory study 12 years policy in Kudus Regency had positive impact in improving the education quality at Kudus Regency, it is seen from the increase of Gross Enrollment Ratio (GER) for secondary education from $60 \%$ in 2008 to $80,59 \%$ in 2013. The success in improving the education quality is also seen from achievement of Kudus Regency in obtained champions in various championships. The supporting factors are The content of the Kudus Regency Regional Regulation Number 2/ 2010 about Compulsory Study 12 Years and the Minister of Education and Culture Regulation Number 80/ 2013 about Universal Secondary Education which clear and easy to understand; the willingness of Kudus Society in receiving the compulsory study 12 years policy; the support funding and scholarships provided by Kudus Regency Government and Central Government. And the inhibiting factors are lack of quality and quantity of human resources (teachers) in Kudus Regency; lack of facilities and infrastructure in supporting the education; the facilities and infrastructure referred is the practice equipments for students that expensive; inequality in educational development at Kudus Regency, especially in rural area; the mindset of Kudus Regency society who ignore the education, especially in rural area; unpredictable conditions such as flood that rather frequently in Kudus, so that damage the education infrastructure.
\end{abstract}

Keyword : Compulsory Study 12 Year Policy, Education Quality, Kudus Regency

Asih Widi Lestari

Email : lestariwidi263@gmail.com

Alamat : Wergu Kulon 106 B RT 04/ I Kudus 


\section{INTRODUCTION}

Constitutions 1945 states that one of Republic Indonesia's goals is increasing the intellectual life of nation, for that every Indonesia citizen has the right to get good education. Good education will result good Human Resources, which is able to actualize the humanity potential optimally [1]. National education is directed to improving the holistic of human dignity that allow the humanity dimension to develop optimally. Therefore, the education institution became a strategic instrument for the effort to develop the individuals potential, including developing national character and national concept for educational member, which became an important foundation to maintenance the National Unity of Republic of Indonesia, so that the ideals of Indonesian human construct can be running completely.

The development of national education that will be done, has considered to international agreements such as Education for All; Convention on The Right of Child; Millennium Development Goals (MDGs) and World Summit on Sustainable Development, which emphasized the importance of education as one way to solve poverty, increase equity and equality of gender; to understand cultural values, multiculturalism, and to increase social justice [2]. But in reality, education in Indonesia has not been fully able to meet the basic rights of citizens. One reason is the unsolved problem of quality education at every and unit levels education, especially primary and secondary education. The indicators of poor quality of education in Indonesia can be seen from the student's achievement that are still very low, the rank of Indonesia education decreased from 65 year to 69 this year [3].

Observing at educational conditions in Indonesia that faced various problems, the various policies also has been formulated. Chief J.O. Udoji [4], defined public policy as: "a sanctioned course of action addressed to a particular problem or group of related problems that affect society at large". One of educational policy that had long held to improve the human resources quality in Indonesia is Compulsory Study Policy. According to Zainir [5], compulsory study is the minimum educational program that should be followed by Indonesian citizen as the responsibility of Central Government and Local Government. Implementation of Compulsory Study in Indonesia based on:
Constitution 1945, Article 31 and 32; Law Number 20/2003 about National Education System, Article 6 which stated that every citizen aged seven to fifteen years must follow compulsory study; Law Number 47/2008 about Compulsory Study, Article 1 Paragraph 1 and 2; and Article 2.

The last compulsory study policy that implemented is compulsory study 9 years. Along with the demands of globalization era and the aim to improve the human resource quality in Indonesia, in mid-2013, Ministry of Education launched the Universal Secondary Education (Pendidikan Menengah Universal) or compulsory study 12 years through Ministry of Education and Culture Regulation Number 80/2013 about Universal Secondary Education

In reality, some regions have been initiated to implement compulsory study 12 years in their respective areas, for example, Surabaya city and Jembrana Regency. Other region that has implemented the policy of compulsory study 12 years is Kudus Regency. This policy has been implemented from 2010 through Kudus Regency Regional Regulation Number 2/2010 about Compulsory Study 12 Year.

However, since the compulsory study 12 years is implemented, in fact, the number of children that drops out from school and collecting school fees in Kudus Regency still exists. Ironically, the main problem is due to economic factors. Moreover, the school cost that increase over time making them difficult continue to their school. Scholarship for Poor Students / Beasiswa Untuk Siswa Miskin is allocated through APBD that amount billion rupiah was not able to resolve this issue. In 2011, a total 3,4 billion has been prepared to succeed compulsory study 12 years policy. While, the distribution funds is leaving problem caused by a database that obviously. As a result, compulsory study 12 years policy that should be able to improve the education quality is precisely vulnerable to misappropriation [6].

Observing an interesting phenomenon, that is the bravery of Kudus Regency issued compulsory study 12 year policy through Regional Regulation Kudus Regency Number 2/2010, while the central government had issued compulsory study 12 year study program in mid-2013. However, in practical area, problems about school dropouts and the practice of collecting school fees is encountered. Then researchers 
interested in conducting research entitled "Implementation of Compulsory Study 12 Years Policy to Increase Education Quality in Kudus Regency". The research objectives of this research are: To know, analyze, and describe about Implementation of compulsory study 12 years policy to increase education in Kudus Regency; To know, analyze, and describe about supporting and inhibiting factors toward implementation of compulsory study 12 years policy to increase education quality in Kudus Regency.

\section{RESEARCH METHODS}

This research is using descriptive qualitative approach. The type and source of data that used in this research are: primary data and secondary data. The data collecting processes that used in this research are: interview; observation; and documentation. In this research, the method of analysis used theory proposed by Miles and Hubberman [7], there are by data collection; data reduction; data presentation; and conclusion/ verification. The research location is in Kudus Regency.

\section{DISCUSSION}

A. Implementation of Compulsory Study $\mathbf{1 2}$ Year Policy to Increase Education Quality in Kudus Regency, consist of:

1. Implementation of Compulsory Study 12 Year Policy in Kudus Regency:

1) Human Resources (Actors) The actors are the stakeholder that required in the implementation of a policy. Likewise, in the implementation of the compulsory study 12 Years policy in Kudus Regency, it is also need a reliable actors to support the success of this policy. In the implementation of the compulsory study 12 Years policy in Kudus Regency that has been conducted since 2010 through Regional Regulation of Kudus Regency Number 2` Year 2010 about Compulsory Study 12 (Twelve) Years, the person in charge is the Regents of Kudus, H. Mustofa. Then in June 2013, the Central Government determined the compulsory study 12 Years through The Regulation of Ministry of Education and Culture of the Republic of Indonesia Number 80 Year 2013 about Universal Secondary Education. After this Regulation of
Ministry of Education and Culture, the Regents of Kudus Regency takes the responsibility of the implementation to the Minister of Education and Culture of Indonesia.

Then, the responsibility of the implementation of compulsory study 12 Years in Kudus Regency transferred to the Education, Youth, and Sports Department as the organization which is responsible in the field of education in Kudus Regency. And in the organizational structure at the Education, Youth, and Sports Department of Kudus Regency, the implementation of compulsory study 12 Years transferred to the Subdivision of Planning, Evaluation and Reporting. Subdivision of Planning, Evaluation and Reporting assisted by Division of Primary Education and Secondary Education.

Meanwhile, the responsible actor for the implementation of Compulsory Study 12 Years Policy in each school is the principal and teachers is the main actors in implementing this policy in each school.

Based on this matter, it can be seen that the actors or stakeholders already know their roles, duties, and responsibilities of each others. The existence of this tasks and authority division, make policy implementation more effective, because the actors have to know well each role and duties. This is certainly in accordance with Soenarko's opinion [8], he said that in supporting the successful implementation a policy, the need for: "effectice division of work; rational division of power and authority in the policy implementation; providing adequate duties and obligations in the policy implementation."

2) Mechanisms of the Implementation;

The mechanism of implementation of Compulsory Study 12 Years in Kudusbased on the Regional Regulation of Kudus Number 2 Year 2010 about 
Compulsory Study 12 (Twelve) Years or the Regulation of Ministry of Education and Culture of the Republic of Indonesia Number 80 Year 2013 about Universal Secondary Education.

The mechanism of implementation of Compulsory Study 12 Years in Kudusbased on the Regional Regulation of Kudus Number 2 Year 2010 about Compulsory Study 12 (Twelve) Years or the Regulation of Ministry of Education and Culture of the Republic of Indonesia Number 80 Year 2013 about Universal Secondary Education.

Kudus Regency has implemented compulsory study 12 Years since 2010 and the only region that has a Regional Regulation which is regulating Compulsory Study 12 Years, namely Regional Regulation Number 2 Year 2010 about Compulsory Study 12 (Twelve) Years. The program of compulsory study 12 (twelve) Years is the vision and mission of the Regents that written in the Regional Regulation Number 4 Year 2009 about The Plan of Medium Term Development of Kudus Regency in 2008-2013.

This compulsory study program aims to improve access and equal distributionof secondary education services that has good quality and achievable for people in KudusRegency, boys and girls through formal and non-formal way. The Regional Regulation Number 2 Year 2010 about Compulsory Study 12 Years determined by the Regent of Kudus on July 22, 2010, and enacted in Kudus by Regional Secretary of Kudus on July 23, 2010. The Regional Regulation Number 2/ 2010 about Compulsory Study 12 (Twelve) Years consists of 14 Articles and Eight Chapters. Chapter One contains of the General Provisions, Chapter Two contains of the Purpose and Objectives, Chapter Three contains of the Implementations, Chapter Four contains of the Management, Chapter Five contains of the Evaluation, Chapter Six contains of the Compulsory Study
Assurance, Chapter Seven contains of the Rights, Obligations, and People Participation, and Chapter Eight contains of Final Provisions.

In 2013, the Central Government determined the compulsory study 12 Years policy through the Regulation of Ministry of Education and Culture of the Republic of Indonesia Number 80 Year 2013 about Universal Secondary Education. Universal Secondary Education is an education program that provides a widest services to all citizen of Indonesia to followthe secondary education that has good quality. The purpose are to provide service, expansion, and equal opportunity to obtain the secondary education that has good quality for every Indonesian citizen with a target achievement of Crude Participations Rates (CPR) of secondary education to $97 \%$ in 2020 .

The Regulation of Ministry of Education and Culture of the Republic of Indonesia Number 80 Year 2013 about Universal Secondary Education determined by the Minister of Education and Culture of the Republic of Indonesia in Jakarta on June 25, 2013 and enacted by the Minister of Law and Human Rights of Republic of Indonesia in Jakarta on June 27, 2013.

The Regulation of Ministry of Education and Culture of the Republic of Indonesia Number 80 Year 2013 about Universal Secondary Education consists of 13 Articles and Eleven Chapters. Chapter One contains of General Provisions; Chapter Two contains of the Goals, Objectives and Scope; Chapter Three contains of the Availability; Chapter Four contains of the Achievability; Chapter Five contains of the Quality; Chapter Six contains of the Certainty, Chapter Seven contains of the Quality Assurance System; Chapter Eight contains of the Funding; Chapter Nine contains of the Evaluation and Reporting; Chapter Ten contains of Division of Authority, Chapter Eleven contains of the Closing. 
The suitable of implementation based on regulations make this compulsory study 12 Year policy is implemented well. This is in accordance with Daniel Mazmanian and Paul A. Sabatier opinion [9]. Daniel Mazmanian and Paul A. Sabatier say that the important role of public policy implementation analysis is to identify variables that affect the achievement of formal objectives in overall implementation process.

These variables are classified into three categories, namely: whether or not to controll the problem that cultivatated; the ability a policy decision to structure appropriately the implementation process; and the direct affect of various political variables toward the balances of support to objectives that set in this policy decisions. One part of variable the ability a policy decision to structure appropriately the implementation process is "the decision rules from implementing agencies/ actors". So, to be able structured the process of policy implementation, must comply with the decision rules from implementing agencies/ actors.

3) The Programs and Amounts of Funds Related with the Compulsory Study 12 Year Policy;

The programs determined by the Government of Kudus in order to support the success of the compulsory study 12 Years policy include: the Development of schools facilities and infrastructure; Routine Maintenance of schools facilities and infrastructure; Rehabilitation of schools facilities and infrastructure; Supplying of books and stationery and also practice equipments; Training and Choaching the teachers in order to enhance the quality of teachers; and so on. Besides of those programs, the Government of Kudus Regency also gives scholarships to students in Kudus, it is scholarships for disadvantaged students and scholarships for students that has achievement in academic and nonacademic.
After the compulsory study 12 Years policy from the Central Government through the Regulation of Ministry of Education and Culture of the Republic of Indonesia Number 80 Year 2013 about Universal Secondary Education, the Central Government determined a program named High School Operational Funding (BOS SMA) and Disadvantaged Student Funding (BSM) to support the implementation of the Universal Secondary Education.

4) Facilities and Infrastructure

Every Year Kudus Regency

Government and the Central Government has spent the budget that use to supply the infrastructure for schools. From the Government of KudusRegency, they have many programs to supply the infrastructure for schools every Year. Meanwhile, the Central Government has Social Funding, one of them is used for investment in infrastucture, such as supply of land, building, and equipments. But, the obstacle is the lack of equipment for practice, this is due to the expensiveness of the equipments.

2. The Increase of Quality Education In Kudus Regency:

The Implementation of Compulsory Study 12 Years Policy in Kudus brings a significance impact in improving the quality of education in Kudus, it can be seen by the improvement of Crude Participant Rates for the secondary education that increased from 60 percent in 2008 to 80,59 percent in 2013. The successful in improving the quality of education in Kudus also can be seen from the achievements of Kudus.

According to the result and achievement, can seen from in the implementation of compulsory study 12 years policy in Kudus Regency give the positive impact to increase quality education in Kudus Regency. The successfully implementation of compulsory study 12 years policy in Kudus Regency also seen from the variables models of implementation public policy from Edward III. George Edward III [10], say that the public policy has been effectively, if concerned 4 variables: 
1. Resource (Actors);

With the availability of support resources, especially human resources. It is related to skills implementers policy to carry out policies effectively.

2. Communication

In regard to how the policy is communicated to the organization and / or the public, the availability of resources to implement the policies, attitudes and responses of the parties involved, and how the organization structures of the implementers of the policy.

3. Disposition;

In regard to the availability of the implementer to carry out the public policy. The skills are not sufficient, without the willingness and commitment to implement the policy.

4. Bureaucratic Structure

With regard to the appropiateness of bureaucratic organizations that be the host of the implementation of public policy. The challenge is how to avoid the bureaucratic fragmentation because this structure makes the process even further than effective implementation.

In the implementation of compulsory study 12 Year policy in Kudus, visibly available responsible actors who execute. The effective communication is established both horizontally and vertically. Horizontally seen from the good communication and coordination actually exists between the Subdivision of Planning, Evaluation and Reporting, Primary Education and Secondary Education.

Socialization of the compulsory study 12 Years policy has been conducted by the stakeholders. Socialization was done through radio and billboards that displayed at the streets of Kudus Regencys. Socialization is given to all stakeholders from the district, village, neighborhood, and schools (formal and informal). Every Wednesday, Kudus Regent visits to the rurals (Tilik Desa) to introduce the compulsory study 12 Years to rural people.

Socialization is also conducted by the Department of Education, Youth, and Sports in Kudus Regency to the principal and teachers when Official Meeting and
Plenary Meeting. Meanwhile, the vertical communication from Ministry of Education and Culture of the Republic of Indonesia can be seen in the presence of socialization of Universal Secondary Education; BOS Program; and Disadvantaged Students Assistance Program through circulars and instructions technical released and addressed to all of Senior High Schools in Indonesia. Disposition actor seen from the actors already know their respective duties. As for the bureaucratic structure in the implementation of compulsory study in Kudus Regency has been good arranged in the Department of Education, Youth, and Sports in Kudus Regency.

B. Supporting and Inhibiting Factors towards Implementation of Compulsory Study 12 Years Policy to Increase Education Quality in Kudus Regency

1. Supporting Factors

a. The Content of the Kudus Regency Regional Regulation Number 2/ 2010 about the Compulsory Study 12 Years and the Minister of Education and Culture Regulation Number 80/ 2013 about the Universal Secondary Education Which Clear and Easy to Understand

According to Soenarko [11], one of the factors that support the successful of implementation the policy is "the content and the purpose of the policy should be clearly understood beforehand". All other terms and provisions that contained in the Regional Regulation of Kudus Number 2 Year 2010 on Compulsory Study 12 (Twelve) Year and Regulation of the Minister of Education and Culture of the Republic of Indonesia Number 80 Year 2013 on Universal Secondary Education has been very clear and detailed in every article.

b. The Commitment of the Kudus Regency Government and the Central Government in Realizing the Compulsory Study 12 Years

Daniel Mazmanian and Paul A. Sabatier [12] said that the important role of implementation analysis of the state policy is to identify the variables that affect the 
achievement of formal objectives in the overall implementation process.

These variables are classified into three categories, namely: the problem is easy or not to be controlled; The ability of a policy decision to structure appropriately the implementation process; and the direct effect of various political variables on the balance of support for the objectives that listed in the policy decisions. One of the part of direct effect variable of various political variables on the balance of support for the objectives that listed in the policy decision is "commitment and leadership abilities of the executive officers".

The commitment of the Kudus Government and the Central Government in realizing the compulsory study 12 Years is one of the key that compulsory study 12 Years policy goes well in Kudus Regency. The commitment of Kudus Government has been known since 2010 through a policy that created,theRegional Regulation Number 2 Year 2010 about Compulsory Study 12 (Twelve) Years. The commitment of the Kudus Government also seen in the vision and missions of Kudus Regent, one of it is makes the compulsory study 12 Years becomes one of the main pillars in development of Kudus Regency. Meanwhile, the commitment of the Central Government with the released of Universal Secondary Education Policy through the Regulation of Minister of Education and Culture Number 80 Year 2013. Then,to success the Universal Secondary Secondary Education policy, the central government also released BOS programs (School Operational Fund) for High School and BSM (Disadvataged Students Fund) for High School.

c. The Willingness of Kudus Society in Receiving the Compulsory Study 12 Years Policy

According to Soenarko [13], one of the factors that support the successful of policy implementation is "approval, support, and public trust". Meanwhile, according to Anderson [14] said that one of the reason for the community to implement a policy is "Public respect to authority and decisions of government agencies; The awareness to accept the policy".

Attitudes of Kudus people who are willing to accept a compulsory study 12 Years policy is one of the supporting factors the continuity of compulsory education 12 Years policy implementation in Kudus Regency. This can be seen through the enthusiasm of the Kudus people in receiving this policy. Public enthusiasm has been seen during the socialization of this policy. There was no citizen who reject this policy but completely support this policy.

d. The Support Funding and Scholarships Provided by Kudus Regency Government and Central Government

The existence of support funding and scholarships from Kudus Government and Central Government are the supporting factor that increasingly the steadiness of the compulsory study 12 Years policy implementation in KudusRegency. The resource of this funding is essential, so that the planned programs running smoothly.

\section{Inhibiting Factors}

a. Lack of Quality and Quantity of Human Resources (Teachers) in Kudus Regency

According to Soenarko [15], the policy implementation that have been formulated well may give impact or not because of several things that are very basic and fundamental. One of these was "There is a lack of available in supporting sources", one of it is human resources.

Each phase of the implementation requires human resources that has good quality in accordance with the work implied by the policy. However, the implementation of compulsory study 12 Years policy in Kudus Regency is inhibit by a lack of human resources 
(teachers), both in quality and quantity.

b. Lack of Facilities and Infrastructure in Supporting the Education

Every Year, the Central Government and the Kudus Government are planning a funds for supporting the equipment of education implementation, but actually did not meet the needs of each school yet. Facilities and infrastructure in referred is the supporting equipment in the implementation of educational, such as equipments for language labs, physics, chemistry, and so on.

\section{c. Inequality in Educational Development \\ Inequality of educational} development in Kudus Regencyi s one of the obstacles in the implementation of compulsory study 12 Years in KudusRegency. Inequality of educational development that occurred in almost all regions. Education development in urban areas is easier than the education development in rural areas.

d. The Mindset of Kudus Regency Society Who Ignore the Education

Changing one's mindset is not easy. Same with changing the mindset of Kudus people to pay attention in the importance of education. There are some Kudus people who still dispassionate in education, especially people in remote areas. Many of them are considered that working in the fields is better than having school. They are also dropouts or did not continuing to school due to the demands of parents, to marry someone and forced to work.

\section{e. Unpredictable Conditions}

Soenarko [16] explained that the implementation of policies that have been formulated well may bring the impact or not due to the several things that are very basic and fundamental, one of it is "the uncertainty of internal or external factor". The uncertainty of external factors in the form of unexpected conditions that occur, such as a natural disaster or other calamity.

Kudus Regency is an area that is prone with flood. Flood almost come every Year, but the flooding that occurred at the end of 2013 was the greatest flood ever occurred in KudusRegency in the last 10 Years. Almost all of the Kudus Regency flooded, absolutely, this flood damage the existing infrastructure in the Kudus Regency. Including the educational infrastructure, many schools are flooded for a few days and was damaged the buildings and infrastructure. It happened in such a way that is unexpected by the Kudus Government.

\section{CONCLUSION AND RECOMMENDATION}

\section{A. Conclusion}

1. The Implementation of Compulsory Study 12 Years Policy in Kudus has been successed. It can be seen from the actors of this policy implementation have completely right in carried out their duties and responsibilities, the funding and programs from regional government and central government, support the mechanism of the imlementation run smoothly accord with the provision.

2. The Implementation of Compulsory Study 12 Years Policy in Kudus brings a significance impact in improving the quality of education in Kudus, it can be seen by the improvement of Crude Participant Rates for the secondary education that increased from 60 percent in 2008 to 80,59 percent in 2013. The successful in improving the quality of education in Kudus also can be seen from the achievements of Kudus Regency become the winner in various competitions.

3. The Supporting Factors in the Implementation of Compulsory Study 12 Years Policy in Kudus are: The content of the Kudus Regional Regulation Number 2 Year/ 2010 about Compulsory Study 12 (Twelve) Years and The Regulation of Indonesian Minister of Education and Culture Number 80/ 2013 about Universal Secondary Education which is clear and easy to understand; The 
commitment from the Kudus Regency Government and the Central Government in realizing the Compulsory Study 12 Years; The willingness of Kudus Society in receiving the Compulsory Study 12 Years Policy; The support funding and scholarships provided by Kudus Regency Government and Central Government.

4. The Inhibiting Factors in the Implementation of Compulsory Study 12 Years Policy in Kudus are: Lack of the quality and quantity of the human resources (teachers) in Kudus Regency; Lack of facilities and infrastructure in supporting the education in Kudus Regency. The facilities and infrastructure referred is the practice equipments for students that expensive; The inequality in education development at Kudus Regency, especially in rural area; The mindset of Kudus Regency Society who ignore the education, especially in rural area; The unpredictable conditions such as flood that rather frequently in Kudus, so that damage the education infrastructure.

\section{B. Recommendation}

1. The Kudus Government and the Central Government should be increase the quantity of education human resources (teachers) in Kudus. It is needs some training activities for the presence education workers (teachers) in improving their qualities.

2. The Kudus Government and the Central Government should be increase the funding in completing the supporting facilities and infrastructure such as the practice equipments for students.

3. The Kudus Government shouls make a policy about the alocation of special funds for education development in rural areas so that not occure the unbalanceness in the urban and rural areas.

4. The Kudus Government needs to having socialization to rural areas about the imprtance of education, so that the people willing to continue their school to higher levels.
5. The Kudus Government should provides the alocation of special funds in repairing the education infrastructure that broken, especially in the distrube area of flood and another disasters.

\section{ACKNOWLEDGEMENTS}

I would like to express my special thanks to my supervisors Drs. Andy Fefta Wijaya, MDA, Ph.D and Dr. Siti Rochmah, MS; my parents Eny Rahayu and Kusmen, SH; my sister Asih Widi Mulyani, S.Pd ; my candidate husband Serda SBA Dhika Bagus Wicaksono, $\mathrm{SH}$ and his family; and all my friends for their contribution, input, and funding to my research completion.

\section{REFERENCES}

[1] Departemen Pendidikan Nasional. 2001. Menuju Pendidikan Dasar Bermutu dan Merata. Jakarta : Komisi Nasional Pendidikan

[2] Badan Perencanaan Pembangunan Nasional (Bappenas). 2009. Program Pembangunan Nasional 2000-2004. Available Online 16 Juli 2013 from http://www.bappenas.go.id

[3] Rahardjo, Mudjia. 2011. Peringkat Indonesia Semakin Menurun. Available Online 16 Juli 2013 from http//: www.mudjihardjo.com

[4] Abdul Wahab, Solichin. 2008. Analisis Kebijaksanaan : Dari Formulasi ke Implementasi Kebijaksanaan Negara. Edisi 2. Jakarta : Bumi Aksara.

[5] Zainir. 2011. Makna Wajib Belajar Sembilan Tahun. Available Online 16 juli 2013 from http:// www.zainir.blogspots.com

[6] Amalia Risky. 2013. Analisis Kebijakan Publik Peraturan Daerah Kabupaten Kudus Nomor 2 Tahun 2010 tentang Wajib Belajar 12 (Dua Belas) Tahun. Available Online 16 Juli 2013 from http:// riskyamalia. blogspot. com.

[7] Miles, Matthew B, Michael. A. Huberman. 1984. Analisis Data Kualitatif. Bandung : PT Remaja Rosdakarya.

[8] Soenarko SD. 2000. Public Policy : Pengertian Pokok Untuk Memahami Dan Analisa Kebijaksanaan Pemerintah. Surabaya : Airlangga University.

[9] Abdul Wahab, Solichin. 2008. Analisis Kebijaksanaan : Dari Formulasi ke Implementasi Kebijaksanaan Negara. Edisi 2. Jakarta : Bumi Aksara. 
[10] Nugroho, Riant. 2009. Public Policy. Jakarta : PT. Elex Media Komputindo Kelompok Gramedia.

[11] Soenarko SD. 2000. Public Policy : Pengertian Pokok Untuk Memahami Dan Analisa Kebijaksanaan Pemerintah. Surabaya : Airlangga University.

[12] Abdul Wahab, Solichin. 2008. Analisis Kebijaksanaan : Dari Formulasi ke Implementasi Kebijaksanaan Negara. Edisi 2. Jakarta : Bumi Aksara.

[13] Soenarko SD. 2000. Public Policy : Pengertian Pokok Untuk Memahami Dan Analisa Kebijaksanaan Pemerintah. Surabaya : Airlangga University.

[14] Anderson. 1979. Public Policy Making. New York : Hol, Rine and Winston.

[15] Soenarko SD. 2000. Public Policy : Pengertian Pokok Untuk Memahami Dan Analisa Kebijaksanaan Pemerintah. Surabaya : Airlangga University.

[16] Soenarko SD. 2000. Public Policy : Pengertian Pokok Untuk Memahami Dan Analisa Kebijaksanaan Pemerintah. Surabaya : Airlangga University. 